

\title{
Study on the Detection of Misfiring Cylinder in a Multi-Cylinder Diesel Engine Loaded on the Practical Machinery
}

by Youhei KAWAMURA ${ }^{\mathrm{a}}$, Masuyuki UJIHIRA ${ }^{\mathrm{b}}$, Kenta KIRIMOTO ${ }^{\mathrm{c}}$,

Sumitoshi OGATA $^{\mathrm{c}}$, Shouichi NAKAMURA ${ }^{\mathrm{d}}$ and Kiyoshi HIGUCHI ${ }^{\mathrm{b}}$

a. Student of Graduate School of Engineering, Hokkaido University, Kita-ku, Sapporo 060-8628, Japan

b. Dept.of Mineral Resources Engineering, Graduate School of Hokkaido University

c. Dept.of Information Science, Graduate School of Kyushu Institute of Technology

d. Machinery Div. of Yamazaki Construction Co., Ltd.

As a motive power in heavy construction machineries including mining and various construction works, a multi-cylinders type of diesel engine is very often used because of its high cost performance. Steady maintaining of diesel engine's operation is substantial in view of economic demands and environmental concerns. To realize this, a practice of early diagnosis and early repair are essential.

In our previous study using a V-12 type of diesel engine installed on a bench, we demonstrated that a misfiring cylinder could be detected by statistical analysis method using rms value of the acceleration waveforms measured on a single point of the engine block.

In this paper, the same experimentation and analyses as in the previous study were conducted for two practical machineries that loaded the same type engine of the previous study. Even though the engine was loaded on a practical machinery, it was found that a misfiring cylinder could be detected by the same way as in the previous study. In addition to the analyzing method in the previous study, in this study, we employed a wavelet transform method with the Gabor function as a window, and analyzed the acceleration waveforms. The results of wavelet analysis revealed that a misfiring cylinder could be detected visually from time-frequency charts. With the aid of statistical analysis using rms value, a misfiring cylinder in a multi-cylinder diesel engine can be doubly checked by wavelet analysis.

KEY WORDS : Multi-Cylinder Diesel Engine, Combustion Diagnosis, Misfiring Cylinder, rms Value, Wavelet Transform

1.は じめに

鉱山機械や建設機械用のディーゼルエンジンにおいては，電気 系統，燃料ポンプ・インジェクタ等の燃料系統，ターボチャー ジャ・吸排気バルブ等の吸排気系統, メタル軸受け・ピストンリ ング等の摺動部など様々な個所で故障が起きる。これらの故障原 因の一つにオイルの劣化が挙げられる。オイルに金属粉や岩粉が 混入するとピストンとシリンダ間で摩耗を引き起こし，オイルパ ンへの燃料の漏れやオイル粘度の低下を招く(仁木，1997)。オイ ルパン中のオイルはエンジン全体を循環しているため，オイルの 劣化はエンジンに致命的損傷を与える恐れがある ( 鈴木ら，1994， 1996)。作業現場においてエンジンに不燃の気筒が発生した場合,

* 2002 年 1 月 7 日受付 4 月 1 日受理

1. 学生会員 北海道大学大学院生 工学研究科環境資源工学専攻

2. 普通会員 工博 北海道大学大学院助教授 工学研究科環境資源工学専攻

3. 工博 九州工業大学大学院助手 情報工学研究科

4. 工博 九州工業大学大学院教授 情報工学研究科

5. 山建設 (株) 機械部長

6. 普通会員 工博 北海道大学大学院教授 工学研究科環境資源工学専攻

[ 著者連絡先 ] FAX 011-706-6319 (北大工・資源)

キーワード：多気筒ディーゼルエンジン，燃焼診断，不燃気筒，rms 值，ウェー ブレット変換
検査・修理中に大気中の岩粉がオイルへ混入する可能性がある （伊与木，1997）。これを最小に抑えるには，不燃気筒を確実に判 定しオイル循環部の開放個所数と開放時間を最小限に抑える必要 がある。ディーゼルエンジンの異常診断で広く採用されている方 法はオイル分析である (中村, 1997 ; 吉長ら，1998)。オイル分析 法では，月単位でオイル中の微量金属成分量を分析し，経時変化 を追い異常個所を判定する。この方法は有効であるが，即時性に 欠ける久点を持っており, より簡易で確実かつ迅速に判定できる 実用的判定法の開発が望まれている。

著者等は重機の使用環境を考慮した場合の計測法として，計測 が簡便な加速度計の利用が適切と考える。これまでの研究におい て, 溝型鋼 (SS400 製) で組まれたベンチ (台座 : 幅 $700 \mathrm{~mm} \times$ 長さ $1,500 \mathrm{~mm} \times$ 高さ $545 \mathrm{~mm}$ ) に載せたエンジンに対しては, エンジン ブロックの 2 個所で測定した加速度波形の自己相関分析, rms 值 の統計解析を行うことで重機用多気筒ディーゼルエンジンの不燃 気筒の判定が可能であることを確認している（川村・氏平ら， 2001)。本研究ではエンジンの所定の位置に最少必要数の加速度計 を常時固定しておき，波形信号データを携帯電話等で解析の専門 技術者がいる事務所へ伝送し，不燃気筒を判定するシステムの構 
築を進めている。したがって実際の計測はエンジンが車両に搭載 された状態で行う必要がある。本論文では前報で用いたエンジン と同型のエンジンを搭載した 2 台の実機に対し, 前報と同様の実 験および解析を行った。実機状態のエンジンの振動波形とベンチ テストの状態の振動波形を比較した結果を述べると共に，前報の 解析方法により実機状態であっても不燃気筒の判定が可能である ことを述べる。また, 前報の解析手法に加え, 加速度波形のウェー ブレット解析法を用い，振動波形の特徵および不燃気筒を判定で きるかどうかを調べた。その結果に基づき， ウェーブレット変換 值の時間一周波数表示によっても，不燃気筒を視覚的に判定でき る可能性があることを述べる。

\section{2. 実 験 方 法}

本実験はエンジンが車両に搭載された通常の使用状態で行っ た。図 1 に実機を用いたディーゼルエンジンの加速度測定法概念 図, 図 2 に測定状況の写真を示す。実験では前報のベンチテスト による実験に用いた V 型 12 気筒ディーゼルターボエンジン (CAT - 3412 型）と同型のエンジンを搭載した $45 \mathrm{t}$ ダンプトラック (CAT - 773B)2 台を使用した。表 1 に使用したダンプトラックの諸 元を示す。以後, 2 台のダンプトラックは「実機 I」,「実機 II」と して区別する。また, 前報のベンチテスト状態での計測結果は「べ ンチテスト」として比較に用いる。図 3(A)(B) に実機Iおよび実機 II の個所別修理・故障度数のヒストグラムを示す。実機 I のダン



図 1 実機を用いたディーゼルエンジンの加速度測定法概念図

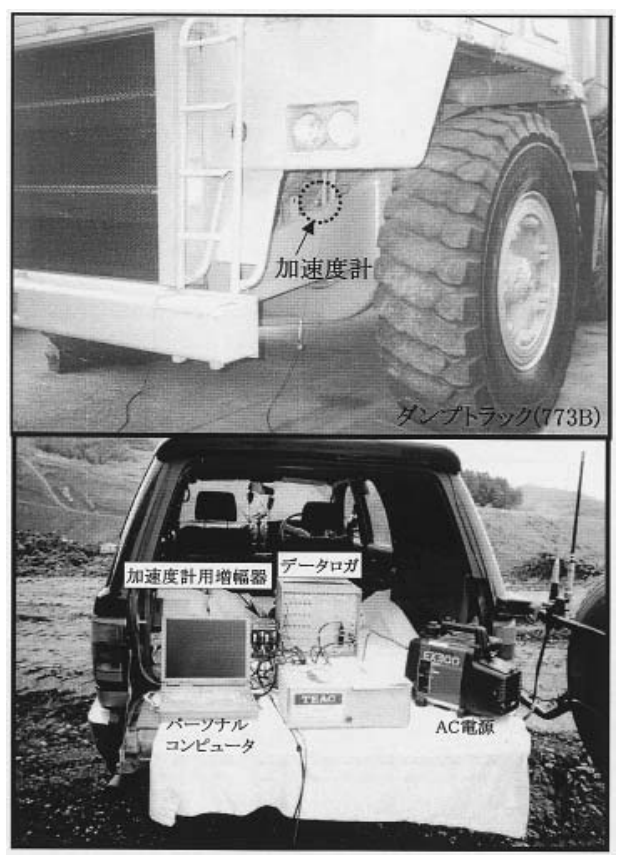

図 2 測定状況の写真
プは新車購入時からエンジンのオーバーホールを行わずに約 1 万 7 千時間 (12 年 7 か月 ) 使用した機械であり, 実機 II は 1 万時間使 用後オーバーホールを行い, その後 7 千時間 (9 年 1 か月) 使用し た機械である。エンジンに関しては，修理回数が実機 I は 31 回, 実機 II は20 回であり, 使用時間も修理回数も少ない実機 II の工 ンジンの方が劣化は少ない。また図 3(A)(B) からエンジン部と足 廻り部がともに修理・故障度数が多いことがわかる。エンジン部 の修理・故障の原因は, オイル循環部への燃料混入や噴射ノズル の目詰まり等である。実験ではエンジン表面の 7 番気筒および 6 番気筒燃焼室側面の 2 個所に加速度計を取り付けることにより振 動測定を行う。エンジンをアイドリング状態にし，不然気筒のな い正常な状態および 1 番気筒から順に 12 番気筒までを 1 気筒ずつ 人為的に不燃気筒にして振動測定を行った。各気筒の不燃状態は 噴射ポンプから高圧パイプで送られてくる燃料を噴射ノズル手前 でカットすることにより発生させた。加速度計はTEAC 社製 708LF (外形寸法 $15 \mathrm{~mm} \phi \times 27 \mathrm{~mm}$, 可測範囲土 $1,470 \mathrm{~m} / \mathrm{s}^{2}$, 周波数特性 $40 \mathrm{kHz}$ ) を使用した。加速度計用増幅器の増幅率は 10 倍とした。 これにより $1.02 \mathrm{mV} /\left(\mathrm{m} / \mathrm{s}^{2}\right)$ の出力感度が得られる。気筒の配置 は図 1 右下に示すように奇数番気筒と偶数番気筒の 6 気筒ずつが $65^{\circ}$ の角度で抱き合わされた構造となっており, 燃焼順序は実機 I, II とも 1-4-9-8-5-2-11-10-3-6-7-12 である。な お, 加速度計の取り付けには耐熱性瞬間接着剂を使用した。加速 度計により測定された出力信号はデータロガに取り込み, パーソ

表 1 実験に使用したダンプトラックの機械仕様 (CAT-773B)

\begin{tabular}{|c|c|c|}
\hline \multicolumn{2}{|c|}{ 全装備重量 } & $38,850 \mathrm{~kg}$ \\
\hline \multicolumn{2}{|c|}{ 全 $\quad$ 長 } & $9,120 \mathrm{~mm}$ \\
\hline \multicolumn{2}{|c|}{ 全 } & $4,065 \mathrm{~mm}$ \\
\hline \multicolumn{2}{|c|}{ 全 } & $4,230 \mathrm{~mm}$ \\
\hline \multirow{2}{*}{ ベッセル } & 平 積 & $26 \mathrm{~m}^{3}$ \\
\hline & ツせル 積 & $31.4 \mathrm{~m}^{3}$ \\
\hline \multirow{6}{*}{$I$} & 式 & CAT-3412 \\
\hline & 定格出力 & $659 \mathrm{ps}(2000 \mathrm{rpm})$ \\
\hline & 重 量 & $2587 \mathrm{kgw}$ \\
\hline & 前 & $1800 \mathrm{~mm}$ \\
\hline & 幅 & $1000 \mathrm{~mm}$ \\
\hline & 高 & $1600 \mathrm{~mm}$ \\
\hline \multirow[t]{2}{*}{ ジ } & シリンダ配列 & $65^{\circ} \mathrm{V}-12$ \\
\hline & シリンダ内径(ボフ & $137.2 \mathrm{~mm}$ \\
\hline \multirow[t]{3}{*}{ ン } & 行程(ストロロクク) & $152.4 \mathrm{~mm}$ \\
\hline & 総排気量 & $27023 c c$ \\
\hline & 噴射方式 & 直接噴射 \\
\hline
\end{tabular}

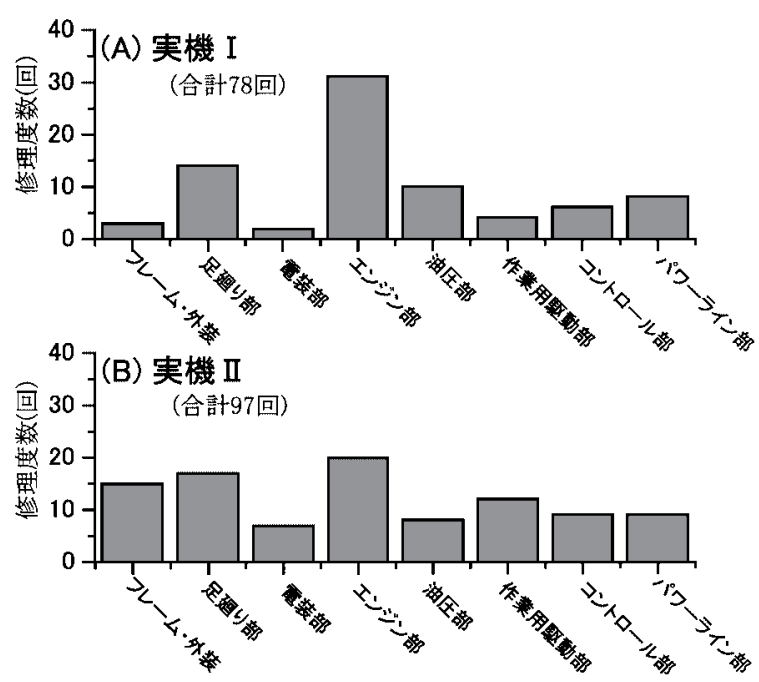

図 3 実験に使用したダンプトラックの個所別修理・故障度数 


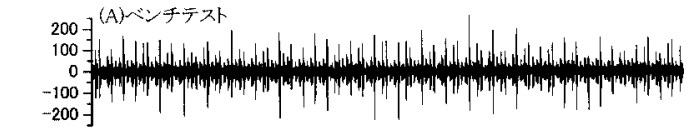

要
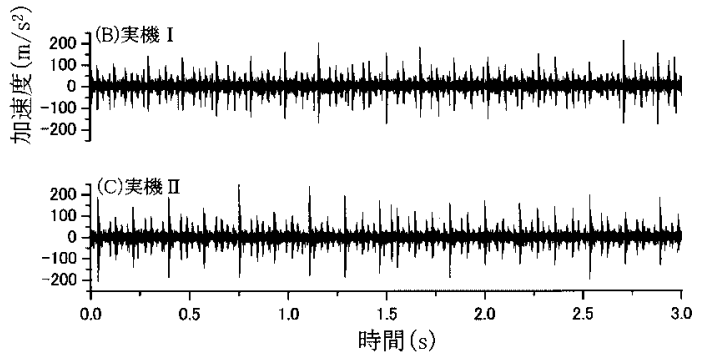

図 4 測定された加速度波形例 (7 番気筒燃焼室側面の加速度計による)

ナルコンピュータ上で波形解析を行った。

\section{3. 解析波形と波形スペクトルの特性}

図 4 に本研究で計測した加速度波形を示す。図 4 に示寸 3 つの 加速度波形は 7 番気筒燃焼室側面に取り付けた加速度計で計測し たものであり，不燃気筒のない正常状態の加速度波形である。図 4(A) はベンチテスト, 同図 (B) は実機 I, 同図 (C) は実機 II の加速 度波形を示している。3つの図の横軸は時間 $(\mathrm{s})$, 縦軸は加速度 $(\mathrm{m}$ $\left(\mathrm{s}^{2}\right)$ である。エンジン回転数はベンチテスト状態では約 $1,000 \mathrm{rpm}$, 実機 I および実機 II では約 $700 \mathrm{rpm}$ である。図 4 からどの波形も $200 \mathrm{~m} / \mathrm{s}^{2}$ を超える大きな振幅が確認できる。この周期的なスパイ ク状の振幅部分は加速度計を 7 番気筒燃焼室側面に取り付けてい ることから，7 番気筒の燃焼振動に対応している。図4(B) および (C) から実機状態の計測による加速度波形の振幅の大きさと周期 は類似していることがわかる。図 4(A) のベンチテスト状態での加 速度波形は他の 2 つの加速度波形と比べ，込み入った，周期の短 い波形になっている。しかしこれはベンチテスト状態と実機状態 で振動の特徴が変化したわけではなく, エンジン回転数の違いに よるものである。少なくとも実機に搭載しているエンジンが車両 のフレームやエンジン連結部の影響を受けて特異な振動をしてい るとはみられない。

図 5 は図 4 に示した加速度波形に FFT 処理を施した結果を示し ている。図 5(A) はベンチテスト, 同図 (B) は実機 I, 同図 (C) は 実機 II の加速度波形のフーリエスペクトルである。3つの場合と も, 卓越周波数は約 $3.3 \mathrm{kHz}$ 付近にみられる。実機 I, 実機 II の場 合の回転速度 $700 \mathrm{rpm}$ は秒単位でみると $11.7 \mathrm{rps}$ である。3つのエ ンジンはそれぞれ 12 気筒ではあるが, クランクシャフト 1 回転で 6 気筒が燃焼している。したがって $1 \mathrm{~s}$ 当たりの燃焼回数は約 70 回である。ピストンーコンロッドークランクシャフトーエンジン ブロックの経路をたどって伝播する振動を加速度計が捕捉してい るのであれば, 少なくとも $11.7 \mathrm{~Hz}$ あるいは $70 \mathrm{~Hz}$ 付近の周波数成 分が大きく表れるはずであるが，フーリエスペクトルでは顕著に 表れていない。 $3.3 \mathrm{kHz}$ 付近の周波数成分は燃焼衝撃で直接エンジ ンブロックに生じた振動成分と推定される。ベンチテストと実機 では $1 \mathrm{k} \sim 2 \mathrm{kHz}$ のスペクトル強度に若干の違いがみられるが, 測 定された加速度波形の周波数成分は 3 つを約 $1 \mathrm{k} \sim 6 \mathrm{kHz}$ の範囲 内に収まっており，大きな違いはみられない。これは 3 つの場合 の波形に 4. で述べるウェーブレット解析を施すと同様の周波数 帯に変化が表れることを示唆している。

\section{4. 連続ウェーブレット解析}

エンジンの燃焼振動は周期性があり，気筒ごとの受け持つ燃焼
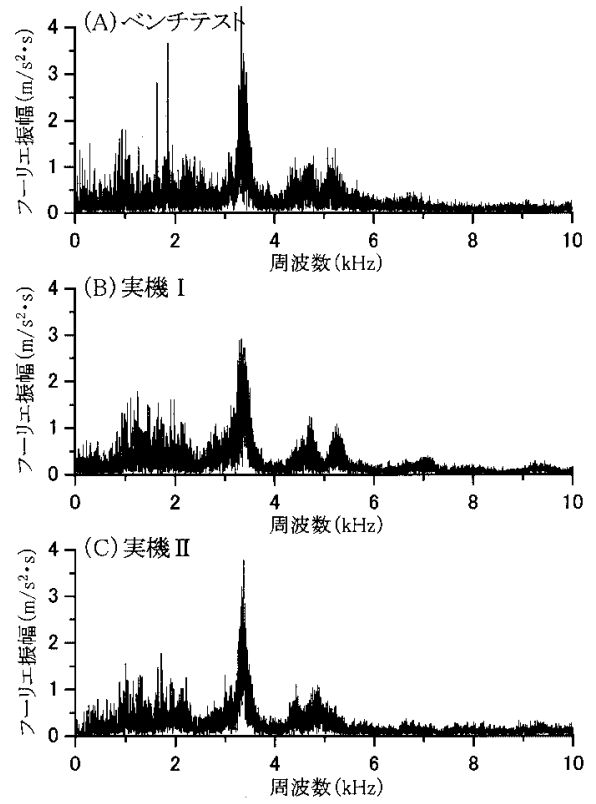

図 5 加速度波形 (図 4)のフーリエスペクトル

時間帯が存在する。このことから, 不燃気筒の判定には時間領域 を含む解析法が有用と考えた。その一つはウェーブレット解析に よる時間一周波数解析であり, もう一つは $\mathrm{rms}$ 值を用いた時間一 振幅解析である。本章ではウェーブレット解析を適用した解析結 果を述べる。

エンジンの異常燃焼をウェーブレット解析により検出した事例 は少ない。菊池ら (1992) は, 自動車用 8 気筒ガソリンエンジンの ノッキング信号に対しガウス型マザーウェーブレットを用いた ウェーブレット解析を行い, この発生を診断できる見通しを得た としている。ただし, 点火時刻がわかるガソリンエンジンについ てである。回転機械の異常診断に関しては土屋ら (1998) はポンプ の音響故障診断システムにウェーブレット変換を用いた診断法を 組み込み, 軸受が損傷したポンプの振動音を正常な振動音と比較 することで故障原因を推定できたと述べている。吉田ら (1998) は 粉末焼結歯車の制振特性をウェーブレット解析により評価してい る。増田ら (1998) は稼動中の機械が発生する仮想的な異常信号の ディコンボリューション処理に関する研究を行っており, 雑音か らの異常信号の抽出を実現している。しかし, 本研究で得られた ようなディーゼルエンジンの加速度波形にウェーブレット変換を 適用し，不燃状態を解析したという研究事例は見当たらない。

本章では測定された加速度波形に連続ウェーブレット変換を施 し, 時間一周波数解析を行った結果を示す。

\section{$4 \cdot 1$ 連続ウェーブレット変換}

ウェーブレット変換は, 測定した振動波形にある周波数と振幅 を持つ局在する波形を重祆合わせ, 両者の積を求める解析方法で ある(榊原，1995)。これにより，時間一周波数解析を行うことが できる。具体的には測定した振動波形にマザーウェーブレットと 呼ばれる局在波形を重祆合わせて積を求める解析方法である（金 ら，1997）。図 6 に本解析で用いたマザーウェーブレット (ガボー ル $\sigma=8 ）$ を示す。この図で見られるように，マザーウェーブレッ 卜は一定の周波数を持つが波形の両端が減衰する関数で表され る。

\section{$4 \cdot 2$ 加速度波形の連続ウェーブレット解析結果}

連続ウェーブレット変換によって得られる結果は, ウェーブ レット変換值の時間一周波数マップとして出力する ( 以後, 単に 


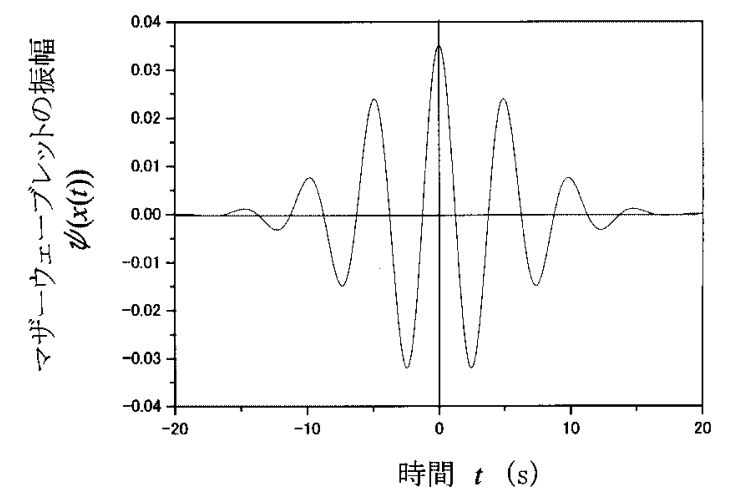

図 6 解析で用いたマザーウェーブレット (ガボール $\sigma=8)$

時間一周波数マップと呼ぶ $。$ 時間一周波数マップとは横軸に時間 (s), 縦軸に周波数 $(\mathrm{kHz})$ をとり，信号に含まれる周波数成分の相 対的な大きさを明度值で与える図である。図 7 は 7 番気筒燃焼室 側面の加速度波形の時間一周波数マップである。同図の (A), (B), (C) はそれぞれ正常状態のベンチテスト，実機 I, 実機 II の各時間一 周波数マップである。各図上部の数字は燃焼気筒 (奇数番気筒) を 示している。この場合, 7 番気筒燃焼室側面で測定しているため, 奇数番気筒の燃焼振動をより明瞭に捉えており, 同じ列に属する 奇数番気筒の燃焼時間に着目する。どの図も加速度計取り付け気 筒である 7 番気筒の燃焼時間帯に特に明度の高い縦縞が見られて いる。一方, 加速度計から遠い気筒の振動は暗くなる。これは加 速度計から遠い気筒で発生した振動はエンジンブロックを伝播し
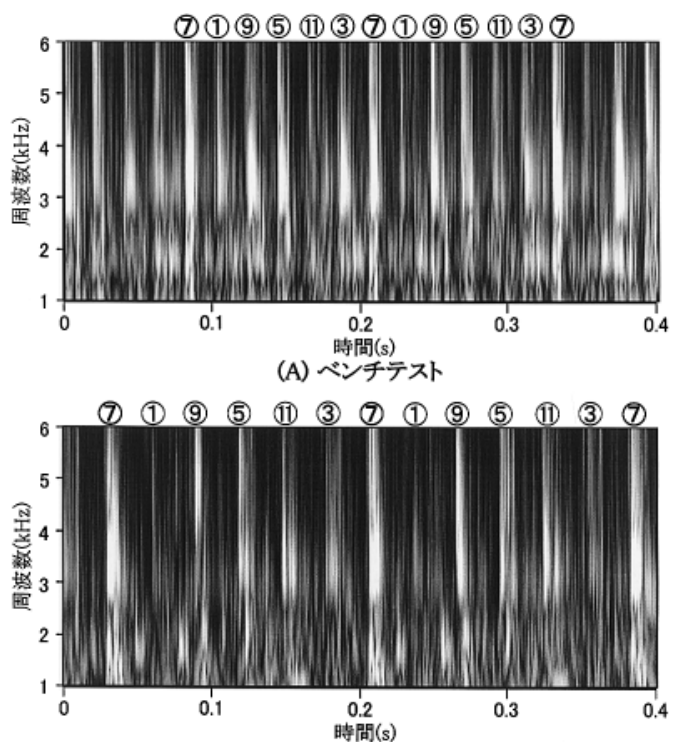

(B) 実機 I

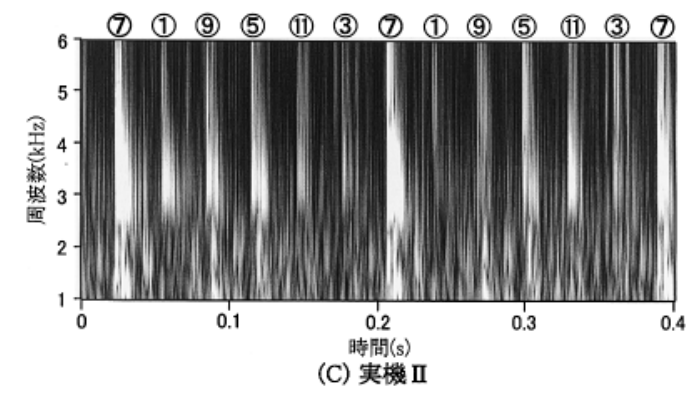

図 7 正常状態における各個体の時間一周波数マップ ( 7 番気筒燃焼室側面)
加速度計に届く間に減衰することを示している。しかし，程度の 差はあるがどれも奇数番気筒の燃焼時間帯に明度の高い縞が見ら れる。実機状態である図 7(B),(C) とベンチテスト状態である同図 （A）を比較しても，目立った変化はなくどちらも各気筒の燃焼時 間帯の約 $3 \mathrm{k} \sim 4 \mathrm{kHz}$ の間に特に高明度の縦縞が集中している。

\section{$4 \cdot 3$ 連続ウェーブレット変換による不燃気筒の判定}

図 8 は実機 I の加速度波形の時間一周波数マップの例を示して いる (加速度計は 7 番気筒燃焼室側面に取り付けている)。同図の (A),(B),(C) はそれぞれ不然気筒のない正常状態の, 7 番気筒不燃状 態のときの, 11 番気筒不燃状態のときの各時間一周波数マップで ある。周波数軸方向に明瞭な縞模様が見られる。図 8(A) では程度 の差はあるが奇数番気筒の燃焼時間帯に明度の高い縞が見られ る。図 8(B),(C) では同図 (A) と比較して, 不燃状態にした気筒の 燃焼時間帯が暗く現れており不燃気筒発生を判定できるといえ る。図 9(A),(B),(C) に示している実機 II における時間一周波数マッ プにおいても全く同様のことがいえる。以上のように，加速度波 形に対しガボール $(\sigma=8)$ マザーウェーブレットを用いた連続 ウェーブレット解析では, FFT 処理結果に比べ時間一周波数マッ プ上に時間情報も含まれるため, 不燃気筒の判定が可能であるこ とを示した。しかし, 周波数帯によっては不燃状態のときも比較 的明度の高い縞が残ることがあるため, 不燃気筒の判定は若干あ いまいになる。

本研究では, エンジンの加速度波形を解析することにより，簡 易, 確実, 迅速に不燃気筒を判定するシステムの確立を念頭に置 いている。著者等はrms值の統計解析による方法と本研究のウェー ブレット解析法を併用することが望ましいと考えている。ウェー

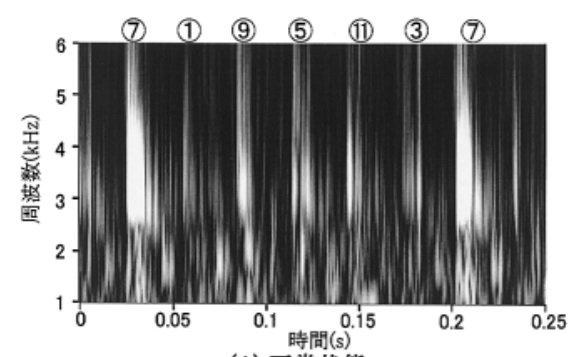

(A) 正常状態

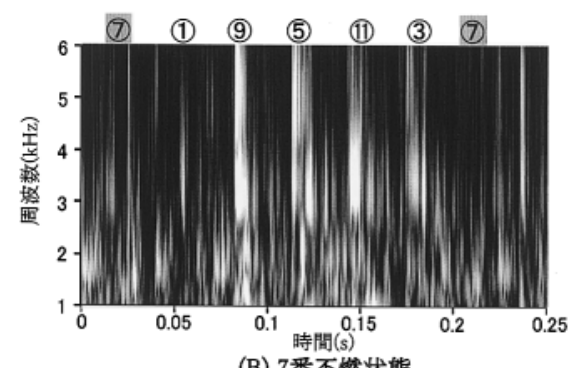

(B) 7 番不然状態

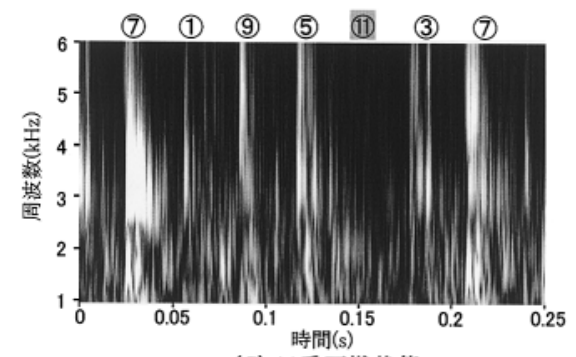

(C) 11 番不矮状態

は不燃気筒を示す

図 8 実機 I で計測した加速度波形のウェーブレット解析結果 (7 番気筒燃焼室側面 ) 
ブレット解析法を用いた不燃気筒の判定法は統計的な判定ではな いため，燃焼状態のバラツキにより判定の正確さが多少失われる とう短所が存在する。しかし，rms 值の統計解析による方法と比 心゙, 解析波形の時間区切りがあいまいであっても解析が行え, 視 覚的に不燃気筒を判定できる長所があるため, 不燃気筒の判定に 併用すべき有用な手段の一つとみなせる。

\section{5. rms 值を用いた統計的解析による不燃気筒の判定}

本章では前報で提唱した rms 值を用いての統計的解析法を実機 に適用した結果を示す。

\section{$5 \cdot 1 \mathrm{rms}$ 值を用いた統計的解析方法}

加速度計取り付け気筒の燃焼から始まり再度取り付け気筒が燃 焼する 1 周期の時間を 12 等分して各気筒の燃焼時間帯を決め, 分 割された時間帯別に加速度波形の rms 值を算出する。 rms 值の計 算は下式に従った。ここで, 右辺根号内の $a_{n}$ は $1 \mathrm{~m} / \mathrm{s}^{2}$ で除する ことで rms 值を無次元化して表すものとする。

$$
\mathrm{rms} \text { 值 }=\sqrt{\frac{1}{m} \sum_{n=1}^{m} a_{n}{ }^{2}}
$$

ただし，

$a_{n}:$ 時間の関数 (時刻 $n \Delta t$ での加速度)

$n:$ 時刻番号

続いて 1 つの振動波形から 1 ～12 気筒までを 1 サイクルとして 10 サイクル分の 10 個の rms 值を算出する。振動測定による不然 気筒の判断は，不燃気筒の $\mathrm{rms}$ 值が正常状態の $\mathrm{rms}$ 值より下回っ ているかどうかで調べる。しかしある気筒が不燃状態になったこ

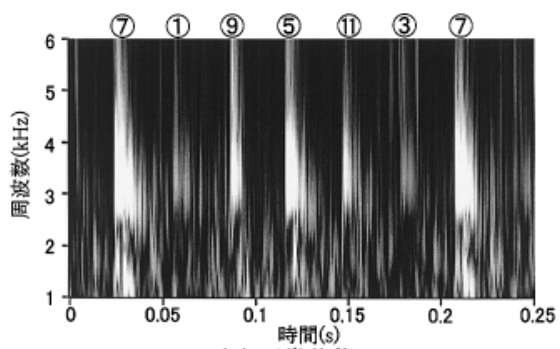

(A) 正常状撽

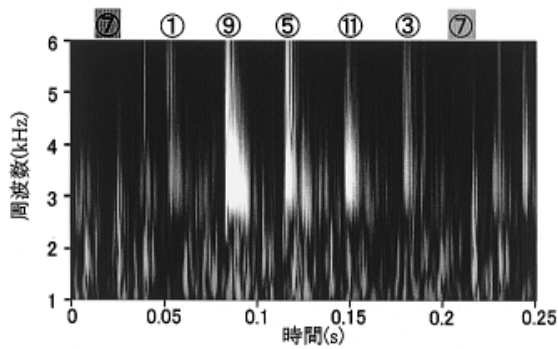

(B) 7 番不燃状態

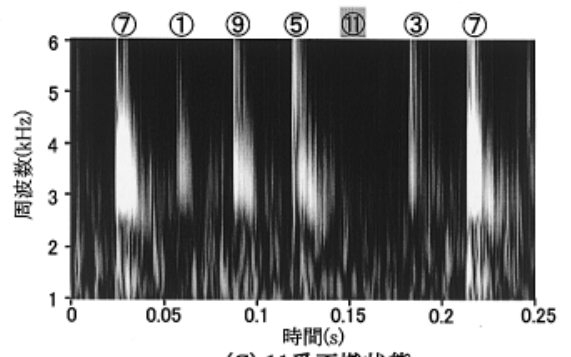

(C) 11 番不撚状態

は不燃気筒を示す

図 9 実機 II で計測した加速度波形のウェーブレット解析結果 (7 番気筒燃焼室側面 )

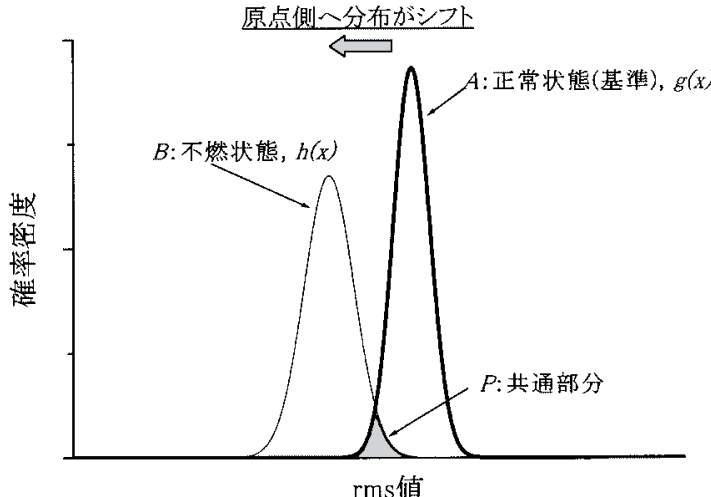

図 $10 \mathrm{rms}$ 值に関する分布が重なる確率概念図

とで他の気筒の rms值が減少あるいは増加傾向を示寸場合もあり, 統計的判定が必要である。正常状態の rms 值と不燃状態の rms 值 が正規分布に従うことは既報で確認しているため， 2 つの分布が 重なる確率を尺度として不燃気筒の判定を行うことができる。

図 10 の概念図に示すように, 正常状態の rms 值の正規分布曲線 を $g(x)$, 不燃状態の rms 值の正規分布曲線を $h(x)$ とする。ここで 注目気筒が正常状態の正規分布を $A$, 不燃状態のときの正規分布 を $B$ と見立てると, $\left(A \cap B^{c}\right) \cup\left(B \cap A^{c}\right)$ の面積 $R$ は次の式 (2) で求 められる。

関数 $g(x)$ および $h(x)$ を離散化して $\left(2^{\prime}\right)$ の形にすると, 数值積分 ができる。

$$
\begin{aligned}
& R=\int_{0}^{\infty}|g(x)-h(x)| d x \\
& \cong \sum_{k=0}^{\infty}\left|g\left(x_{k}\right)-h\left(x_{k}\right)\right| \Delta x
\end{aligned}
$$

$A, B$ どちらの面積も 1 なので, 共通部分 $A \cap B$ の面積 $P$ は $P=$ $1-R / 2$ により求められる。実際の解析結果ではそのまま $P$ を 100 倍し，パーセントで表示寸る。

\section{$5 \cdot 2$ 不燃気筒の統計的判定結果}

ここでは，気筒の正常，不燃状態の判定を $\mathrm{rms}$ 值の正規分布を 用い全気筒にわたって行った結果を示す。

表 2 および表 3 はそれぞれ実機 I，実機 II におけるP の值を\% で表示したものである。表中の (A)(B) はそれぞれの 6 番気筒と 7 番気筒に取り付けた加速度計による解析結果である。表中の太枠 で示した值はある特定気筒を不燃状態にしたときのその気筒の $P$ の值を示している。それぞれの最上段には不燃気筒がない場合の $P$ の值を示している。表中の*がついた值はある気筒を不燃状態 にしたときの rms 值の正規分布の平均值が，基準となる正常状態 のときの rms 值の正規分布の平均值を上回っていたときの重なり 合う確率值である。今回の実機を用いた実験では, 実機 I, 実機 II ともに不燃状態ではない気筒の $\mathrm{rms}$ 值の平均值が, 正常状態の正 規分布の平均值をかなり上回り正規分布の重なり合う確率が小さ くなる現象が多くみられた。図 11 は基準となる正規分布の平均值 ( 全気筒正常状態) をかなり上回った正規分布の例である。つまり 不燃気筒のない正常状態の 9 番気筒の $\mathrm{rms}$ 值の正規分布と, 7 番 気筒が不燃状態になったときの 9 番気筒の rms 值の正規分布の重 なり具合を示したものである。

ベンチテストの結果でも，同様の現象は見られたが，正規分布 の重なり合う面積が大きく, 不燃気筒の判定には支障がないと判 断した。しかし, 実機にエンジンを搭載した今回の場合は不燃気 筒発生時の rms 值の正規分布の平均值が, 正常状態の rms 值の正 規分布の平均值を上回る度合いが大きいため, 重なり合う確率が 
表 2 実機 Iにおける正規分布の重なり具合の確率 (*はrms 值の分布が原点と反対側にシフトした場合の確率值)

(A) 測定点6番 (単位\%)

\begin{tabular}{|c|c|c|c|c|c|c|c|c|c|c|c|c|}
\hline 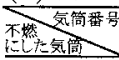 & 1番 & 2番 & 3番 & 4番 & 5番 & 6番 & 7番 & 8番 & 9番 & 10番 & 11番 & 12番 \\
\hline & 48.9 & 64.7 & 51.3 & 48.0 & 31.3 & 56.3 & 62.4 & 82.5 & 73.6 & 83.6 & 72.6 & 71.9 \\
\hline 不然1番 & 60.2 & 22.9 & *16.6 & 56.4 & $* 21.6$ & $* 42.6$ & $* 43.3$ & 88.9 & $* 70.6$ & 76.1 & $* 0.2$ & 71.0 \\
\hline 22番 & 65.7 & $36.0 \times 10^{-7}$ & 22.5 & $* 23.6$ & $* 10.6$ & $* 52.9$ & $* 4.2$ & $* 38.5$ & 10.9 & 40.8 & 43.0 & 74.1 \\
\hline " 3番 & 46.2 & 16.4 & $5.9 \times 10^{-7}$ & $* 35.8$ & $* 3.3$ & 39.5 & $425.8 \times 10$ & $* 24.8$ & 19.4 & $* 2.8$ & $* 7.9$ & $* 32.0$ \\
\hline$\|$ 4番 & 36.7 & 22.0 & 11.2 & $3.2 \times 10^{-12}$ & $* 0.1$ & 26.2 & $* 7.3$ & $* 27.1$ & 9.0 & 30.9 & $* 41.9$ & 87.9 \\
\hline $\begin{array}{l}n 5 \text { 5 } \\
\end{array}$ & 35.7 & *25.3 & 7.4 & 38.1 & $28.4 \times 10^{-8}$ & 74.9 & $* 1.5$ & $* 17.6$ & $* 18.7$ & 90.3 & $\frac{8.2}{8.2}$ & $* 65.5$ \\
\hline II 66番 & 48.5 & 22.1 & 8.1 & 51.1 & $* 21.8$ & $16.9 \times 10^{-12}$ & $* 10,5$ & $* 55.3$ & 11.5 & 69.2 & $* 27.9$ & $* 61.3$ \\
\hline II 7番 & 17.1 & 38.4 & 13.5 & $* 29.4$ & 6.1 & $* 15.5$ & $23.9 \times 10^{1}$ & $* 28.4$ & 16.8 & *30.1 & $* 8.8$ & 17.8 \\
\hline "II8雷 & 34.6 & 22.2 & 6.3 & 24.7 & $* 2.9$ & 8.3 & $* 2.1$ & $41.5 \times 10^{12}$ & 8.9 & & 6 & $* 69.8$ \\
\hline II99番 & 64.0 & 63.4 & 29.0 & $* 18.9$ & $* 6.8$ & $* 49.5$ & $* 0.1$ & $* 23.9$ & $97.8 \times 10^{-3}$ & $* 40.7$ & $* 16.9$ & $* 47.1$ \\
\hline "I 10番 & 58.9 & 26.4 & 56.8 & 41.9 & $* 3.7$ & 4.1 & $* 22.5$ & $* 37.6$ & 29.6 & $79.4 \times 10^{-4}$ & $* 43.8$ & 66.5 \\
\hline I111番 & 49.3 & 26.2 & 1.7 & 12.3 & $* 1$ & 34.5 & $9 \times 10^{-2}$ & $* 253$ & 435 & & $6 \times 10^{-8}$ & 2586 \\
\hline 12番 & 47.2 & 14.9 & 9.7 & 45.1 & $* 4.5$ & $* 68.8$ & $* 9.7$ & 79.8 & 2.2 & $* 69$. & $* 11.9$ & $3 \times 10^{-7}$ \\
\hline
\end{tabular}

(B) 測定点 7 番 (単位\%)

\begin{tabular}{|c|c|c|c|c|c|c|c|c|c|c|c|c|}
\hline 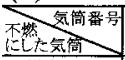 & 僠 & 2番 & 3番 & $\begin{array}{l}\text { 4番 } \\
\end{array}$ & 5番 & 6番 & ?番 & 8番 & 9番 & $\overline{10 \text { 番 }}$ & 11番 & 12番 \\
\hline 不燃大次 & 83.2 & 35.4 & 51.5 & 77.7 & 58.5 & 78.4 & 81.9 & 69.7 & 57.9 & 33.0 & 80.4 & 53.8 \\
\hline 不燃1番 & $10.2 \times 10^{-5}$ & 29.8 & 85.5 & 34.0 & 94.9 & $* 43.2$ & $* 47.6$ & $* 61.9$ & $* 21.1$ & $* 27.7$ & $* 0.2$ & $* 24.2$ \\
\hline $\begin{array}{l}\text { "2 2番 } \\
\end{array}$ & $\$ 13.4$ & $.3 \times 10^{-}$ & $* 61.4$ & 44.8 & $* 76.8$ & $* 28.6$ & & 27.9 & $* 10$ & $* 58.9$ & $* 63.6$ & $* 70.0$ \\
\hline n 3番 & $* 67.9$ & $* 18.8$ & $1.6 \times 10^{-3}$ & 28.0 & 79.4 & 61.9 & $* 9$ & $* 15.6$ & $* 13.5$ & $* 16.9$ & $* 26.6$ & $* 6.7$ \\
\hline "ll4番 & $* 55.3$ & 23.6 & $* 73.3$ & $8 \times 10^{-12}$ & *82.7 & $* 59.1$ & $* 64$ & 23.9 & $* 84.4$ & $* 9.4$ & 99.4 & $* 0.6$ \\
\hline II 5番 & $* 47.1$ & 1.2 & $* 69.7$ & 7.2 & $18.5 \times 10^{-12}$ & $* 43.5$ & & $* 62.9$ & $* 14.1$ & $* 48.7$ & $* 43,1$ & $* 35.5$ \\
\hline $\begin{array}{ll}71 & \text { 6番 }\end{array}$ & 72.5 & $* 4.9$ & $x_{1}^{*}$ & 0.7 & $* 76.3$ & 1.9 & & 19.9 & $* 75.9$ & $* 6.1$ & 39.0 & $* 23.6$ \\
\hline II7番 & 47.3 & $* 44.1$ & $* 39.7$ & 0.3 & $* 64.5$ & $* 25.5$ & $.3 x$ & $* 70.2$ & $* 9.1$ & 8.7 & $* 9.9$ & 23.8 \\
\hline "I 8番 & $* 73.8$ & $* 10.5$ & $* 46.2$ & 13.9 & 80.3 & $* 76.9$ & & $70.7 \times 10^{-5}$ & $* 46.3$ & $* 7.8$ & $* 47.5$ & $\$ 48.4$ \\
\hline 1) 9番 & 75.3 & $* 12.8$ & $* 1.7$ & 13.1 & $* 3$ & $* 47.8$ & & 63.8 & $13.8 \times 10^{-12}$ & 29.9 & *45.4 & $* 51.6$ \\
\hline II 10番 & $* 86.8$ & $* 23.5$ & $* 39.8$ & 23.5 & $* 38.7$ & $* 36.9$ & $* 78.4$ & 46.4 & $* 40.2$ & 1.8 & $* 35.4$ & 18.6 \\
\hline $\begin{array}{ll}\text { "11番 } \\
\end{array}$ & $* 82.8$ & $* 54.8$ & $\begin{array}{ll}74.2 \\
\end{array}$ & 0.4 & $* 64.8$ & $* 652$ & & 193 & & 233 & $18.9 \times 10^{-10}$ & $* 864$ \\
\hline II 12番 & $* 48.6$ & $* 38.1$ & $* 41.5$ & 87 & $* 796$ & 577 & $* 99$ & 37 & $* 503$ & 865 & ald & 5 \\
\hline
\end{tabular}

表 3 実機 II における正規分布の重なり具合の確率 ( *はrms 值の分布が原点と反対側にシフトした場合の確率值) (A) 測定点6番 (単位\%)

\begin{tabular}{|c|c|c|c|c|c|c|c|c|c|c|c|c|}
\hline 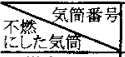 & 1番 & 2番 & 3番 & 4番 & 5番 & 6番 & 7番 & 8番 & 9番 & 10番 & 11番 & 12番 \\
\hline 不燃なL & 82.7 & 65.9 & 74.2 & 68.9 & 71.8 & 84.2 & 24.8 & 83.6 & 90.5 & 72.1 & 84.5 & 60.1 \\
\hline 不燃1番 & $47.0 \times 10^{-3}$ & $* 19.7$ & *36.6 & $* 10.6$ & *59.5 & $* 6.2$ & $* 38.5$ & $* 85.3$ & $* 56.1$ & $* 32.1$ & $* 69.9$ & 83.1 \\
\hline "I2番 & 70.7 & $16.0 \times 10^{-12}$ & *35.6 & $* 35.8$ & $* 77.4$ & $* 3$ & 46.5 & $* 99.4$ & $* 9.8$ & 60.3 & $* 51.1$ & *95.0 \\
\hline "I3番 & 32.5 & $* 19.8$ & $11.0 \times 10^{-4}$ & $* 25.17$ & $\begin{array}{l}74.3 \\
\end{array}$ & $* 31.6$ & 51.7 & $* 58.5$ & $* 24.9$ & $* 33.2$ & $* 51.1$ & 80.5 \\
\hline II 4䊩 & 51.9 & 31.2 & $* 21.9$ & $10.9 \times 10^{-4}$ & 58.8 & $* 44$ & 60.5 & 25.1 & $* 35.4$ & 55.2 & $* 36.8$ & $\overline{84.3}$ \\
\hline n 5番 & $* 54.0$ & 16.2 & 60.8 & $* 19,5$ & $15.1 \times 10^{-12}$ & $* 63.9$ & 38.8 & & $* 27.8$ & $* 42.9$ & $* 58.1$ & $\overline{87.1}$ \\
\hline 7 6番 & 59.1 & $* 60.4$ & 88.3 & $* 8.3$ & 73.3 & $4.9 \times 10^{-8}$ & 82.1 & $* 78.4$ & $* 47.6$ & $* 43.3$ & $* 41.8$ & 71.7 \\
\hline "17番 & 34.5 & $* 46.6$ & *39.2 & $* 12.1$ & 65.4 & $* 43.2$ & $1 \times 10^{-4}$ & $* 54.4$ & *41.9 & $* 25.0$ & $* 15.2$ & 60.3 \\
\hline "I 8 8番 & $* 76.3$ & $* 54.9$ & $* 40.9$ & $* 40.9$ & 76.9 & $* 71$ & $* 47.2$ & $1.4 \times 10^{-4}$ & $* 60.4$ & $* 34.6$ & $* 59.9$ & $* 48.3$ \\
\hline " 9 9番 & $* 55.4$ & 35 & $* 39.2$ & $* 15.8$ & $* 58.3$ & $* 61$ & 78.7 & *56.8 & 4.3 & *66.1 & *63.1 & $* 78.4$ \\
\hline " 10番 & $* 70.1$ & $* 59.8$ & 89.4 & *23.1 & 73.8 & $* 67$ & $* 25.2$ & 60.7 & $* 56.7$ & $15.7 \times 10^{-3}$ & $* 46.7$ & $* 69.6$ \\
\hline 11 番 & 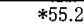 & 30.6 & $* 44.9$ & *16.9 & $* 88.0$ & $* 53$ & $\overline{72.6}$ & $* 62.1$ & $* 14.2$ & $* 39.0$ & $10^{-4}$ & $* 71.5$ \\
\hline "I 12番 & 46.1 & 68.7 & 48.5 & $* 27.1$ & 39.5 & $* 62.8$ & 19.4 & & & $* 63.9$ & & 0.0 \\
\hline
\end{tabular}

(B) 测定点7番 (単位\%)

\begin{tabular}{|c|c|c|c|c|c|c|c|c|c|c|c|c|}
\hline  & 1番 & 2番 & 3番 & 4番 & 5番 & 6番 & 7番 & 8番 & 9番 & 10番 & 11番 & 12番 \\
\hline 不然机 & 88.8 & 74.9 & 80.6 & 60.0 & 91.5 & 53.2 & 75.9 & 66.6 & 82.7 & 47.9 & 72.5 & 77.6 \\
\hline 不燃1番 & $6 \times 10^{-9}$ & *33.5 & $* 37.2$ & & $* 55.9$ & & $* 44$ & 178 & $* 31$ & $* 62.6$ & *63.9 & $* 58.6$ \\
\hline "I 2番 & $* 72.9$ & 0.9 & $* 60.7$ & $* 19.3$ & 69 & $* 0.4$ & $* 14$ & $* 19.6$ & $* 3.7$ & $* 7$ & $* 93.7$ & $\overline{8.1}$ \\
\hline II3番 & 55.8 & *21.0 & $5 \times 10^{-7}$ & $* 93.3$ & *81.7 & 71.4 & $* 26.7$ & $* 53.8$ & $* 47.6$ & 1 & $* 22.3$ & $* 51.1$ \\
\hline "1番 & $* 60.4$ & *38.4 & $* 47.1$ & $75.5 \times 10^{-4}$ & 72.9 & *11.1.1 & & $* 0.4$ & $* 71.5$ & & 36.8 & $\overline{21.1}$ \\
\hline " 5 番 & $* 19$. & 31.0 & $F_{4}^{*}$ & $* 30.6$ & $8 \times 10^{-1}$ & $* 1$ & & 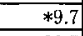 & $* 8^{\prime}$ & & $* 31.3$ & 45.6 \\
\hline "I 6番 & $* 84.7$ & $* 0$. & $* 45.5$ & & 96.9 & 0.1 & $* 67.5$ & 82.5 & $* 29$ & $* 3$ & $* 50.1$ & $\overline{53.3}$ \\
\hline I" 7 7 & 67.5 & $* 0$ & & & & $499.7 \times 10^{-5}$ & $1.2 \times 10^{-3}$ & $* 0.9$ & & *39.6] & *12,8 & $* 1.6$ \\
\hline " 8 番 & *72.3 & $* 0$ & $* 16.5$ & $* 21.2$ & 6.3 & $* 0.1$ & $* t$ & $41.5 \times 10^{-3}$ & $* 59.1$ & 72.6 & $* 27.8$ & 5.5 \\
\hline 9番 & 213.3 & $=13.9 \times 10^{-5}$ & & $* 18$ & *58.6 & $* 1.2$ & $* 31$ & $\overline{9.6}$ & $\frac{8 \times 10}{8 \times 10}$ & $* 44,9$ & $* 64.3$ & $\star 42.3$ \\
\hline 10番 & $* 38.8$ & $* 0$. & -1 & $\approx 16.1$ & $* 44$ & $* 1$ & & & $* 44$ & 65.6 & $* 35.3$ & 44.6 \\
\hline 11番 & $* 29.6$ & $* 0$ & & & 0.9 & & & & & 38.0 & $10^{-3}$ & 60.7 \\
\hline 12 番 & $* 2$ & $*$ & $* 11.1$ & $* 6.5$ & $* 50$ & 80 & & 58.3 & $* 62$. & & *65.7 & $0.0]$ \\
\hline
\end{tabular}

小さくなりベンチテストの場合と同じ処理では正常状態の気筒を 不燃状態と誤認する可能性がある。ベンチテストでは基準となる 正常状態時の正規分布曲線に対し, 不燃気筒発生時の rms 值の正 規分布が右に上回る状態は約 $23 \%$ の燃焼時間帯に見られたが, 実 機を用いた場合では約 $61 \%$ の燃焼時間帯において見られた。これ は不燃気筒の発生により他の気筒の燃焼振動の振幅が正常状態の 燃焼振動の振幅を上回っていることを意味する。実機状態におい てこのような現象が多く起こる原因としては, 燃料噴射量を制御 しているガバナの動作結果にあると判断される。安定したエンジ ンの運転を行うためには, 負荷変動に対して安定した回転数を維 持することが必要である。ディーゼルエンジンの場合, 吸入空気
量がエンジン回転数にかかわらずほぼ一定のため, 発生トルクは, 燃料噴射量により決定している。ガバナはエンジンの回転を安定 的に維持し, エンスト, オーバーランにならないよう制御するた めにエンジン回転数を検知して目標回転数との差を検出する機 能, 目標回転数との差分に応じた噴射量制御を行うためのコント ロールラックを動かす作動力を発生させる機能を持っている（大 久保, 1979 ; 宮下ら，1994）。本実験の場合，1気筒が不燃状態に なるため, その気筒はエンジン全体の負荷となり, 回転数が減少 する。そこでガバナが機能し他の気筒への燃料噴射量を増加させ る。結果として不燃気筒の発生により他の気筒の燃焼振動の振幅 が正常状態の燃焼振動の振幅を上回る状態が出現する。ベンチテ 


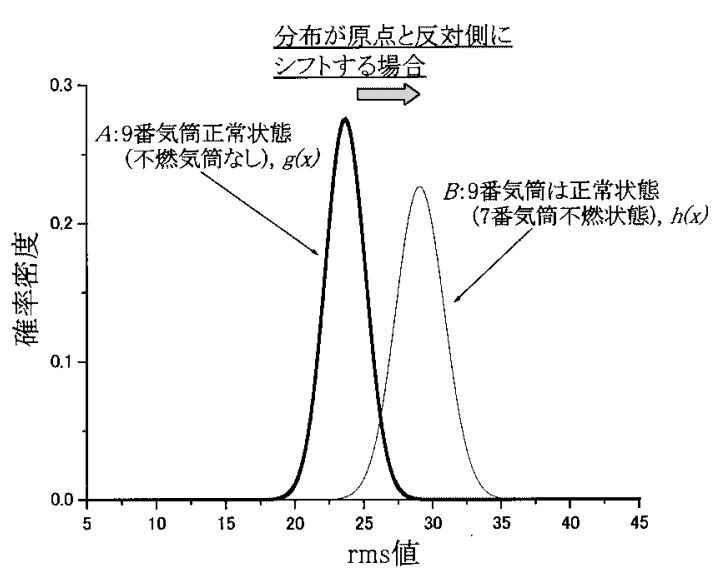

図 11 基準となる正規分布を上回る正規分布の例 (7 番気筒 不燃状態時の 9 番気筒の正規分布 )

ストと実機状態においてその割合が異なるのは，どちらも無負荷 ではあるが，実機状態ではクランクシャフトにかかる負荷がベン チテスト状態よりも大きくなっていることによるものである。

ここで，正常状態の $\mathrm{rms}$ 值の正規分布の平均值を上回る分布に なる場合は, 確実にその気筒は不燃状態ではないため, この後に 続く計算では表中の*のついた值を 100 に置き換え, 重なり合う 確率を $100 \%$ として取り扱うこととする。

実機 I の解析結果である表 2(A),(B) の対応するマス目の確率の 值を掛け合わせた $P^{2}$ を求め, 式 (3) で (dB) 表示して描いたものが 図 12 である。図 13 は実機 II の解析結果である表 3 の值を用いて 同様に $(\mathrm{dB})$ 表示したものである。

\section{実機 I}

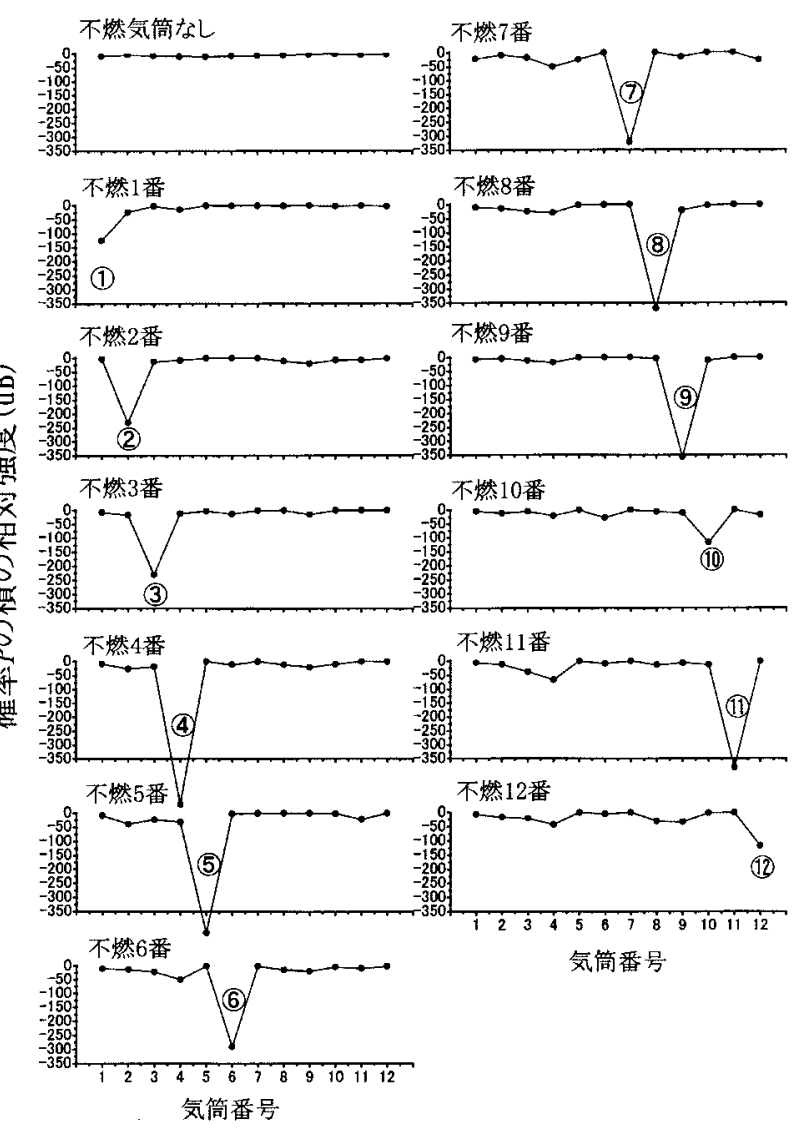

図 12 実機 $\mathrm{I}$ における確率 $P$ の積の相対強度

$$
\left(P^{2} \text { の相対強度 }\right)=20 \log _{10}\left(P^{2} / P_{100}{ }^{2}\right)(\mathrm{dB})
$$

ただし，

$P$ : 正常状態と不燃状態の $\mathrm{rms}$ 值の分布が重なり合う確率 (\%)

$P_{100}$ : 正常状態と不燃状態の $\mathrm{rms}$ 值の分布が同じであるとみな したときの 2 つの分布が重なり合う確率 $(100 \%)$

図 12，13 に示した実機 I, 実機 II の結果は，ともにベンチテスト の結果と同様にエンジンに不燃気筒がない同図左最上段では, ほ ぼ横ばいの一直線になっている。その他の, 不燃気筒がある場合 の 12 個の図では, いずれも不燃気筒に対応寸る燃焼時間帯での確 率の相対強度が小さくなっている。図 12 の実機 I では不燃状態で はない気筒の相対強度にも窪みが見られるが, 不燃状態になった 気筒の窪みは非常に大きく表現されている。図 13 の実機 II でも 実機 I と同様に不然状態になった気筒の窪みは大きく, 不燃状態 でない気筒の窪みがほとんど見られない。これにより, 全 12 気筒 すべての不燃状態を判定することが可能である。

以上のように, rms 值の統計的解析法により, エンジンを車両 に搭載した実機の状態であっても, またエンジンの劣化程度が異 なっていても, 全 12 気筒すべての不燃気筒を判定できることを確 認した。今後は稼動中に突発的に起こった不燃気筒に対し, 計測・ 解析を行い, 本不燃気筒判定システムの信頼性を確かめていきた いと考えている。

$$
\text { 6. ま と め }
$$

本研究ではエンジンの決まった位置に最少必要数の加速度計を 常時固定しておき, 波形信号データを携帯電話等で解析の専門技 術者がいる事務所へ伝送し判定する不燃気筒判定システムの構築 を目指している。本論文では前報で用いたエンジンと同型のエン

\section{実機 II}

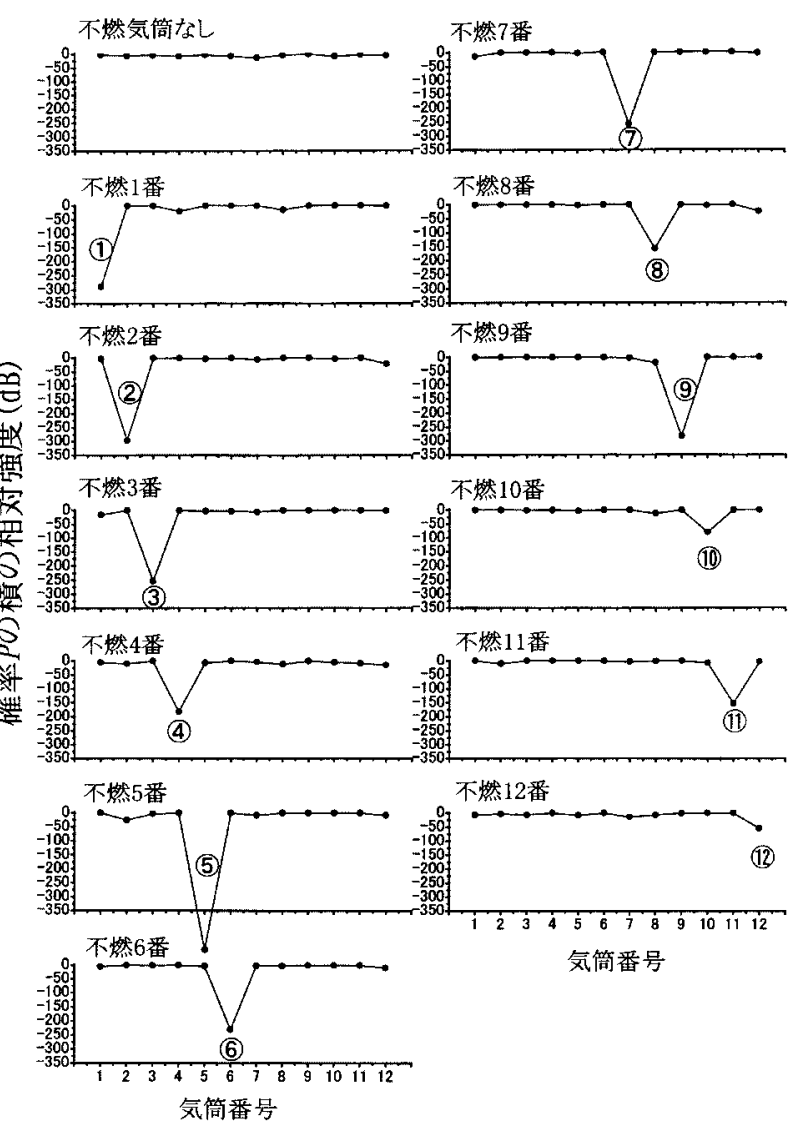

図 13 実機 II における確率 $P$ の積の相対強度 
ジンを搭載した 2 台の実機に対し，同様の実験および解析に加え 加速度波形のウェーブレット解析を行い, 次の点を明らかにした。

1）測定波形の FFT 解析， ウェーブレット解析を行い，エンジ ンを車両に搭載した実機の状態の計測であっても，エンジン燃焼 室側面に取り付けた加速度計から得られる振動波形成分はベンチ テスト状態の計測による振動波形成分と変化がないことを確認し た。

2）ディーゼルエンジンには電気的な点火信号はないが, 加速 度波形をデータ列の任意の位置から連続ウェーブレット変換し変 換值を時間一周波数マップ上に表示することで, マップ上の縦縞 模様から各気筒の燃焼時間帯を特定できる。

3）ウェーブレット解析法を用いた不燃気筒の判定法は統計的 な判定ではないため, 燃焼状態のバラツキにより判定の正確さが 多少失われるという短所が存在する。しかし, rms 值の統計解析 による方法と比べ，解析波形の時間区切りがあいまいであっても 解析が行え，視覚的に不燃気筒を判定できる長所があるため，不 燃気筒の判定に併用すべき有用な手段の一つといえる。

4） rms 值の統計的解析法により,エンジンを車両に搭載した実 機の状態であっても, またエンジンの劣化程度が異なっていても， 全 12 気筒すべての不燃状態を判定できることを明らかにした。

\section{引用 文 献}

芦野隆一・山本鎭男 (1997) : ウェーブレット解析 (誕生・発展・応用), 共立出版, p. $124-196$
チャールズ K. チュウイ著, 桜井 明・新井 勉共訳 (1994)：ウェーブレット入門, 東京電機大学出版局, p. 1-98

伊与木善・山口政房 (1997) : 建設機械の整備上, ユーザーに望むこと, 建設機械, 7 月, p. $11-17$

川村洋平・ 氏平増之・樋口澄志・中村祥一・駒崎征明・伊藤史人 (2001) : 多気筒ディー ゼルエンジンの不燃気筒の判定に関する研究一加速度波形の rms 值を用いた場 合一，資源と素材，Vol. 117, No. 6, p. 485-493

川村洋平・氏平増之・樋口澄志・桐本賢太・駒崎征明・伊藤史人 (2001) : Wavelet 解 析を用いた建設機械エンジンの異常診断に関する研究, 土木学会北海道支部論 文報告集, No. $57(\mathrm{~A})$, p. $42-45$

菊池久和 (1992) : 異常燃焼のウェーブレット解析, 数理科学, No. 354, p. 44-51

金泰九・清水久二 (1997) : ウェーブレット変換を用いた歯車の異常診断, 安全工学, Vol. 36, No. 5, p. $289-295$

増田 新・山本鎭男・曽根 彰 (1998) : ウェーブレット変換を用いた時系列信号の ディコンボリューション(ウェーブレットパケットおよびしきい值処理の導入と 最適化ウェーブレットの生成), 日本機械学会論文集 (C 編), Vol. 64, No. 621, p. $104-111$

宮下直也・黒木秀雄 (1994)：自動車用ディーゼルエンジン, 山海堂, p. 196-214 中村祥一 (1997) : 海外工事における建設機械の管理, 建設機械, 7月, p. 35-39 仁木正明 (1997)：建設機械の整備上ユーザーに望むこと，建設機械， 7 月， p. 18-23 大久保義雄 (1979) : 燃料噴射装置入門, 山海堂, p. 143-286

榊原進 (1995) : ウェーブレットビギナーズガイド, 東京電機大学出版局, p. 1-28 鈴木政治・細谷哲也・中村和夫・曽根康友 (1994) : 油中摩耗粉分析によるディーゼル エンジンの故障診断, 鉄道総研報告, Vol. 8, No. 11, p. 11-16

鈴木政治・細谷哲也・中村和夫・曽根康友 (1996) : 油中摩耗粉分析法によるディーゼ ルエンジンの異物混入故障の診断，鉄道総研報告，Vol. 10, No. 8, p. 17-22

土屋雅弘・高木亨之 (1998) : 回転機械の振動音響診断技術 ( ウェーブレット変換によ る回転機械の故障診断), 日本機械学会論文集 (C 編), Vol. 64, No. 618, p. 85-92 吉田 彰・大上祐司・木脇祐二(1998) : ウェーブレット変換による歯車動的性能の評 価, 日本機械学会論文集 (C 編), Vol. 64, No. 618, p. 318-326

吉長重樹・岩井善郎・本田知己・鈴木 拓 (1998) : 潤滑油中の摩耗粉のリアルタイム 形状解析としゅう動面劣化診断一の応用, 日本機械学会論文集 (C 編), Vol. 64, No. 618 , p. $282-288$ 